\title{
O Shush! An Exclamatory Construction in Hausa
}

\section{Paul Newman}

Hausa is a language that is rich in derivational morphology. While many of the derivations have not been described in detail, most of them are known at least to the extent of their normal phonological appearance and meaning. The purpose of this paper is to describe a derivational construction, the exclamatory $-o o$, that has somehow escaped the attention of Hausa grammarians.'

1. If, for example, a child keeps bothering a parent about a cap (hùulaa), the parent could respond huuloo matà 'Quit bugging me about the cap!'; or if a child is tattling on another child Audu, one could respond Audoo matà 'Shut up, I don't want to hear another word about Audu!'; or if a child is mumbling about having to wait (jiraa) for someone, one could respond jiroo maià 'Be still, that's enough of your complaining about waiting!'. I am not entirely clear about the exact meaning and force of this construction, nor can I specify exactly where it is appropriate to be used. To determine this, careful anthropological/sociolinguistic observation in a natural Hausa setting is needed. From what I have been told, the construction is considered brusque (perhaps even rude or crude), but it is 
pragmatically perfectly acceptable when used by an adult addressing a child. A master might also use it with a servant to show annoyance. A child could possibly use it with another child. An adult would not normally use it with another adult unless he or she really meant to be insultingly abusive.

The suffixal $-0 o$ operates as a deformation of a word overtly expressed in the stimulus sentence or phrase. That is, an expression karoo matà 'Be still about the dog!' could only be used as a response to a sentence containing the word kàree 'dog'. It could not, for example, be used if a child were pointing frantically at a dog while repeating inàa tsooronsà 'I am afraid of it'. Here the response would have to be tsooroo matà 'Don't bother me about your (silly) fear!'?

The matà in the expression is clearly understood to be the indirect object pronoun form 'to her', with 'her' referring to 'mother'. As is so common in cultures of the world, a simple reference to 'mother' in an exclamatory phrase is sufficient to make it abusive (cf. Hausa uwaakà 'Blast you!', lit. 'your mother'). The use of matà here is grammatically interesting in that indirect objects formed with the markers $w \grave{a} / m a$ are normally restricted to a position immediately following a finite verb, a restriction that has prompted some scholars to interpret $w \grave{a} / m a$ as verb suffixes rather than as separate prepositional elements. (See Tuller (1984) for arguments for, and Mohammed (1985) for arguments against this view.) A possible explanation for the use of matà after the exclamatory forms is that this usage reflects the situation postulated for Old Hausa in which matà and the other 'indirect object pronouns' functioned primarily as possessives (see Newman 1982). Thus, huuloo matà would literally have meant not 'cap to/for her', but rather 'her cap'.

In appropriate circumstances the matà can be omitted and left understood, i.e. huuloo $=$ huuloo mata. When this is done, it generally results in a lessening of the abusive quality of the expression.

2. The underlying form of the suffix is $-o o)^{\mathrm{H}}$, i.e. it is a toneintegrating affix with $\mathrm{Hi}$ tone. By tone-integrating, I mean that the Hi tone of the suffix extends over the entire stem to which it is attached, obliterating lexical tone in the process, ${ }^{3}$ e.g.

$\begin{array}{lll}\text { donkey } & \text { jàakii } & \text { jaakoo } \\ \text { cloth } & \text { zanèe } & \text { zanoo }\end{array}$




$\begin{array}{lll}\text { bicycle } & \text { kèekè } & \text { keekoo } \\ \text { fire } & \text { wutaa } & \text { wutoo } \\ \text { ostrich } & \text { jiminaa } & \text { jiminoo }\end{array}$

2.1. The suffix can be added to almost any word, simple or derived, regardless of its part of speech, e.g.

(2)

$\begin{array}{lll}\text { gowns } & \text { rïgunàa } & \text { riigunoo } \\ \text { teachers } & \text { màalàmai } & \text { maalamoo } \\ \text { a Daura man } & \text { bàdàurii } & \text { badauroo } \\ \text { Hausas } & \text { hàusàawaa } & \text { hausaawoo } \\ \text { lioness } & \text { zaakanyàa } & \text { zaakanyoo } \\ \text { Katsina } & \text { kàtsinà } & \text { katsinoo } \\ \text { Hadiza } & \text { hàdiizà } & \text { hadiizoo } \\ \text { read } & \text { kar̈àntaa } & \text { karantoo } \\ \text { drink up } & \text { shânyee } & \text { shanyoo } \\ \text { burying } & \text { bisòo } & \text { bisoo } \\ \text { teaching } & \text { kooyârwaa } & \text { kooyar̃woo } \\ \text { drummings } & \text { kide-kide } & \text { kide-kidoo } \\ \text { white } & \text { farii } & \text { faroo } \\ \text { cooked } & \text { dàfaffee } & \text { dafaffoo } \\ \text { soaking wet } & \text { tsamoo-tsàmòo } & \text { tsamoo-tsamoo } \\ \text { in a mess } & \text { kaca-kaca } & \text { kaca-kacoo } \\ \text { three } & \text { ukù } & \text { ukoo } \\ \text { tomorrow } & \text { gòobe } & \text { gooboo } \\ \text { she } & \text { ita } & \text { itoo }\end{array}$

The -oo suffix attaches freely to compound expressions. Note the spread of the Hi tone over the entire compound.

(3)

$\begin{array}{lll}\text { crocheted mat } & \text { tùmàa-kasà } & \text { tumaa-Kasoo } \\ \text { crockery } & \text { fàadi-kà-mutù } & \text { faadi-ka-mutoo } \\ \text { pimple } & \text { bàr-ni-dà-muugùu } & \text { bar̃-ni-da-muugoo } \\ \text { bangle } & \text { kyàlkyàl-banzaa } & \text { kyalkyal-banzoo } \\ \text { peanut oil } & \text { mân gyàdaa } & \text { man gyadoo } \\ \text { Dutsin Ma } & \text { duutsin-maa } & \text { duutsin-moo }\end{array}$

The suffix can also be used with certain phrasal constructions that 
strictly speaking do not constitute compounds. In such cases, variation exists as to how far to the left the Hi tone extends, e.g.

(4)

$\begin{array}{ll}\text { come! } & \text { yaa kà } \\ \text { go (fem.)! } & \text { jèe ki } \\ \text { twelve } & \text { shâa bìu } \\ \text { nineteen } & \text { àshirin bâa daya } \\ \text { nineteen } & \text { àshirìin daya baabù }\end{array}$

$o o$-Form

yaa koo

jee koo

shaa biyoo

àshirĩin baa dayoo

àshirin daya baaboo

3. As is generally the case with vowel initial suffixes in Hausa, the -oo normally replaces the final vowel of the stem. If the stem ends in a consonant, the $-o o$ is added, e.g.

(5)

$\begin{array}{lll}\text { cloth } & \text { zanèe } & \text { zanoo } \\ \text { money } & \text { kudii } & \text { kudoo } \\ \text { pencil } & \text { fensîr } & \text { fensiroo } \\ \text { cake } & \text { kyât } & \text { kyatoo } \\ \text { Wudil } & \text { wudil } & \text { wudiloo } \\ \text { buses } & \text { bâs-bâs } & \text { bas-basoo }\end{array}$

Consistent with the view that the Hausa diphthongs [ai] and [au] are phonologically complex vowels rather than VC sequences (Newman and Salim 1981; Schuh i.p.), the diphthongs are replaced by the $-\infty$ suffix just like monophthongal vowels, e.g.

(6)

$\begin{array}{ll}\text { pennies } & \text { kwàbbai } \\ \text { Europe } & \text { tuúai } \\ \text { seven } & \text { bakwài } \\ \text { bows } & \text { kibau } \\ \text { Gusau } & \text { gùsau } \\ \text { patience } & \text { jìmrau }\end{array}$

oo-Form
kwabboo
tuuroo
bakoo (/bakwoo/)
kiboo
gusoo
jimroo

In Newman and Salim (1981) it was suggested that syllable-final /n/ tended to fuse with preceding vowels to form 'nasal diphthongs'. That is, syllable-final nasals constitute part of complex nuclei rather than functioning as distinct consonantal codas (see also Newman 1972: 316). It is thus interesting to observe that the -oo suffix 
generally replaces a stem final $-\mathrm{VN}$, as it does with the oral diphthongs, rather than being added to it, as one might expect with C-final stems, e.g.

(7)

$\begin{array}{lll}\text { Ibadan } & \text { bàadùn } & \text { baadoo } \\ \text { Kafancan } & \text { kàfäncàn } & \text { kafancoo } \\ \text { resident } & \text { razdàn } & \text { razdoo } \\ \text { envelope } & \text { ambùlàn } & \text { ambuloo } \\ \text { a gown } & \text { màalùm-maalum } & \text { maalum-maaloo } \\ \text { fifty } & \text { hàmsin } & \text { hamsoo } \\ \text { jet black } & \text { bakii kirin } & \text { bakii kiroo }\end{array}$

With monosyllabic CV(V) words (excepting those ending in /oo/ which simply retain their shape), the -oo suffix replaces the stem-final vowel rather than being added to it. When the $-o o$ is added to a diphthong, the second vocalic component (/i/ or / $\mathrm{u} /)$ automatically alters into the corresponding glide $(/ \mathrm{y} /$ or $/ \mathrm{w} /)$ and becomes the onset of the next syllable. When the -oo is added to a monophthong, a light epenthetic glide is inserted: [y] if the preceding vowel is front, [w] otherwise, e.g.

(8)

$\begin{array}{lll}\text { oil } & \text { mâi } & \text { mayoo } \\ \text { life } & \text { râi } & \text { rayoo } \\ \text { good } & k y a ̂ u & \text { kyawoo } \\ \text { footprint } & \text { sau } & \text { sawoo } \\ \text { eat } & c i & c i^{y} o o \\ \text { me } & \text { nii } & n i^{y} o o \\ \text { you (fem.) } & \text { kee } & k e^{y} o o \\ \text { us } & \text { muu } & m u^{w} o o \\ \text { flat stone } & \text { faa } & \text { faawoo } \\ \text { drink } & \text { shaa } & \text { shaa oo }\end{array}$

With forms such as $n i^{y} o o$ and $m u^{w} o o$ it is debatable whether the glides should be viewed as epenthetic insertions (with automatic shortening of the preceding homorganic vowel) or whether they really represent the stem vowel to which the suffix has been added directly. The form $k e^{y} o o$ is aberrant in that non-final short /e/ in open syllables does not normally occur in Hausa. 
3.1. Verbs with the -oo suffix typically look exactly like ventive (grade 6) verb forms, e.g.

(9)

$\begin{array}{llll}\text { fall } & \text { faadi } & \text { oo-Form } & \text { Ventive } \\ \text { throw at } & \text { jèefaa } & \text { faadoo } & \text { faadoo } \\ \text { read } & \text { kar̃àntaa } & \text { kar̃antoo } & \text { jeefoo } \\ \text { karantoo }\end{array}$

In two cases, however, the resultant forms are not identical. First, with the small class of disyllabic Hi tone $a a$-final verbs, the -oo suffix replaces the final vowel while the ventive adds -woo, e.g.

$\begin{array}{llll} & & \text { oo-Form } & \text { Ventive } \\ \text { call } & \text { kiraa } & \text { kiroo } & \text { kiraawoo } \\ \text { pay } & \text { biyaa } & \text { biyoo } & \text { biyaawoo } \\ \text { wait for } & \text { jiraa } & \text { jiroo } & ---\end{array}$

Second, there is a distinction between the ventive of the verb $c i$ 'eat', which is formed either with -woo or with a /y/glide, and the oo-form, which only occurs with the epenthetic glide, e.g.

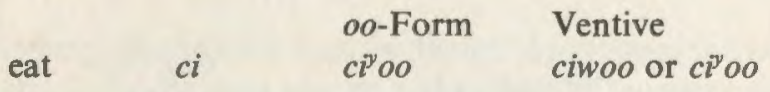

Most Hausaists (e.g. Abraham 1959: 56-57; Parsons 1971/72: 89n) have assumed, implicitly or explicitly, that the underlying form of the ventive suffix was $-\infty 0$ and that the $/ w /$ seen in forms such as ciwoo and kiraawoo was either epenthetic or else belonged to the stem. The evidence presented here supports the view presented in Newman (1977) on historical grounds that the full form of the ventive is really -woo and that its usual appearance as a replacive vowel /oo/ is due to phonological reduction.

4. As is well known, Hausa has a general rule affecting most alveolar obstruents (as well as the glide /w/) that palatalizes them when followed by a front vowel, e.g. kàazaa/kàajii 'hen/hens'; wutaa/wutàacee 'fire/fires'; kàasuwaa/kaasuwooyii 'market/markets'. When a non-front vowel suffix replaces a stem-final front vowel, one normally has to 'undo' the palatalization, i.e. it is the underlying consonant that surfaces, e.g. mijii/mazaa 'husband/husbands'; har- 
shèe/harsunà 'tongue/tongues'. The situation with regard to the -oo suffix is more varied, suggesting that palatalization in Hausa is not a simple synchronic rule affecting all segments equally, but rather is a more complicated rule operating differently for different consonants and at different levels in the grammar.

When $-\infty o$ is added to the palatals $/ \mathrm{sh} /(<\mathrm{s})$ and $/ \mathrm{j} /(<\mathrm{z})$, one normally undoes the palatalization, e.g.

$\begin{array}{lll} & & \text { oo-Form } \\ \text { spear } & \text { maashì } & \text { maasoo } \\ \text { countries } & \text { kasàashee } & \text { kasaasoo } \\ \text { spice } & \text { yaajii } & \text { yaazoo } \\ \text { chest } & \text { kirjii } & \text { kirzoo }\end{array}$

With /c/, depalatalizing to / $/$ normally takes place only in derived and inflected forms. Simple stems tend to keep the $/ \mathrm{c} /$, although there is individual and dialectal difference regarding the treatment of common nouns, ${ }^{6}$ e.g.

$\begin{array}{lll}\text { cars } & & \text { oo-Form } \\ \text { stolen } & \text { mootoocii } & \text { mootootoo } \\ \text { a Sokoto man } & \text { sàataccee } & \text { saatattoo } \\ \text { food } & \text { bàsakkwacèe } & \text { basakkwatoo } \\ \text { Bauchi } & \text { ábinci } & \text { abincoo } \\ \text { Bichi } & \text { bauci } & \text { baucoo } \\ \text { nose } & \text { bicì } & \text { bicoo } \\ & \text { hancii } & \text { hancoo }\end{array}$

Unlike the depalatalization of $/ \mathrm{j} /$ to $/ \mathrm{z} /$, which operates naturally and comfortably, depalatalization of $/ \mathrm{j} /$ to $/ \mathrm{d} /$ seems clumsy and dispreferred, e.g.

\begin{tabular}{|c|c|c|}
\hline & & $\begin{array}{l}\text { oo-Form } \\
\text { gidaajoo or (?) gidaadoo }\end{array}$ \\
\hline & & gudajjoo or (?) $\mathrm{g}$ \\
\hline
\end{tabular}

Remarkably, one speaker depalatalized $/ \mathrm{j} /$ to $/ \mathrm{z} /$ even though the $/ \mathrm{j} /$ was clearly derived from $/ d /{ }^{7}$ e.g. 
(15)

$\begin{array}{ll}\text { gidàajee } & \text { oo-Form } \\ \text { gùdajjee } & \text { gidaazoo } \\ \text { gudazzoo }\end{array}$

Finally, /y/always stays as such and never depalatalizes to /w/, e.g.

$\begin{array}{lll}\text { slaves } & \text { baayii }(<\text { baawàa }) & \text { oo-Form } \\ \text { markets } & \text { kaasuwooyii } & \text { kaasuwooyoo }\end{array}$

5. While the typical use of the oo-form is in a phrase of the type takaridoo matà 'the hell with the paper!', it can, as indicated earlier, be used alone. When the oo-form occurs in pre-pausal position, it is marked by a phonetic feature characteristic of Hi tone (monotonal) verbs with long final vowels, namely final glottalization (see Newman and van Heuven 1981). That is, in pre-pausal position, the ooform ends not in a short vowel (with automatic glottal closure) nor in a long vowel (with normal breathy release), but in a long, phonetically intermediate length, vowel with glottal closure. Compare the $o o$-forms in (17a) with the verb forms in (17b).
a. oo-Forms

paper
hare $^{8}$
gowns
red

b. Verbs

... call (Bello)

... drink (water)

... return (neg)

...p pull-here (for him)
Non-pre-pausal takar̃doo matà zoomoo matà riigunoo matà jaawoo matà

kiraa Bellò shaa ruwaa koomoo ba jaawoo masà
Pre-pausal takar̃doo? zoomoo? riigunoo? jaawoo?

kiraa?
shaa?
koomoo?
jaawoo?

kiraa?

shaa?

jaawoo?

6. In this paper I have provided a sketch of a previously overlooked derivational formation in Hausa. Even this ever so brief description has revealed the remarkable extent to which this exclamatory construction touches on problems in Hausa phonetics, phonology, and morphology. This oo-form invites further and deeper study, from socio-cultural as well as linguistic perspectives. 


\section{Notes}

1. The only previous mention of this formation that $I$ have been able to find is in Bargery (1934: 825), repeated more or less verbatim in Abraham (1962: 708). I am deeply indebted to Ismail Junaidu and Sammani Sani for providing me with a rich array of data on which to base this study, and for helping me to come to an understanding of what this construction is about. [After completing the paper I discovered that Parsons, not surprisingly, knew of this construction and had commented briefly on it, see Parsons 1981: 567-68.]

2. The phrase *tsooronsoo matà was rejected. It appears that one cannot add the $-o o$ suffix to a form containing a cliticized genitive or object pronoun.

3. The distinction between Tone Integrating Affixes, which override lexical tone, and Tone Non-Integrating Affixes, which do not, is described and explained in Newman (1986).

4. Normally, tone non-integrating affixes such as -waa occur outside the stem, to the right of any tone integrating affixes. Note here that the tone integrating -oo is rightmost and includes the non-integrating suffix -waa in its tonal domain.

5. I would contend that the correct explanation for the $/ w /$ and $/ y /$ seen in sawoo and rayoo is the one offered here, and that it has nothing to do with the existence of the dialectal forms saawu $(=s a u)$ and raayii $(=r a \hat{i})$. If the $o o$-forms were really related to the dialect variants, one would necessarily have a long /aa/ in the first syllable (i.e. "saawoo and *raayoo) rather than the occurring forms with the short /a/.

6. In general, whether to undo palatalization or not was the one question regarding the $-o o$ construction where there was the greatest individual speaker inconsistency as well as greatest inter-speaker variation.

7. Although the relationship of $/ \mathrm{j} /$ to $/ \mathrm{d} /$ is usually described as being on a par with that of the other palatal/alveolar pairs, there is good reason to view $/ \mathrm{j} / \sim / \mathrm{z} /$ as the 'real' pairing (historically and synchronically), and the $/ \mathrm{j} / \sim / \mathrm{d} /$ connection as being of a much more tenuous nature.

8. One can minimally contrast the common noun zoomoo 'hare', with normal vowel release, with the exclamatory oo-form zoomoo?, which manifests glottal closure.

\section{References}

Abraham, R. C. 1959. The Language of the Hausa People. London: University of London Press.

- . 1962. Dictionary of the Hausa Language. 2nd ed. London: University of London Press.

Bargery, G.P. 1934. A Hausa-English Dictionary and English-Hausa Vocabulary. London: Oxford University Press. 
Mohammed, Mohammed Munkaila. 1985. Dative constructions in Hausa. MA thesis, SOAS, University of London.

Newman, Paul. 1972. Syllable weight as a phonological variable. Studies in African Linguistics 3 (3): 301-23.

- .1977 . Chadic extensions and pre-dative verb forms in Hausa. Studies in African Linguistics 8 (3): 275-97.

-. 1982. Grammatical restructuring in Hausa: indirect objects and possessives. Journal of African Languages and Linguistics 4 (1): 59-73.

- - 1986. Tone and affixation in Hausa. Studies in African Linguistics 17 (3): $249-67$.

-- and Bello Ahmed Salim. 1981. Hausa diphthongs. Lingua 55: 101-21.

Newman, Roxana Ma, and Vincent J. van Heuven, 1981. An acoustic and phonological study of pre-pausal vowel length in Hausa. Journal of African Languages and Linguistics 3 (1): 1-18.

Parsons, F. W. 1971-72. Suppletion and neutralization in the verbal system of Hausa. Afrika and Übersee 55 (1/2): 49-97; 55 (3): 188-208.

- - 1981. Writings on Hausa Grammar: The Collected Papers of F.W. Parsons, ed. G. L. Furniss. 2 vols. Ann Arbor: University Microfilms International, Books on Demand.

Schuh, Russell, G. In press. Long vowels and diphthongs in Miya and Hausa. In Current Approaches to African Linguistics (Vol. 5), ed. Paul Newman and Robert D. Botne. Dordrecht: Foris Publications.

Tuller, Laurice, 1984. Datives in Hausa. In Proceedings of NELS [Northeastern Linguistic Society] XIV, ed. Charles Jones and Peter Sells, pp. 447-60. Amherst: Graduate Linguistic Student Association, University of Massachusetts. 